\title{
Social Disorganization Theory: The Role of Diversity in New Jersey's Hate Crimes Based on Race and Ethnicity
}

\author{
Dana M. Ciobanu \\ Walden University
}

\begin{abstract}
The purpose of this correlational panel study was to test Shaw and McKay's theory of social disorganization by examining the relationship between demographic diversity and hate crime rates. The study focused on the relationship between the level of diversity, residential mobility, unemployment, family disruption, proximity to urban areas, and population density in all 21 New Jersey counties and hate crime rates. The existing data of Federal Bureau of Investigations' hate crime rates and the U.S. Census Bureau's demographic diversity were operationalized as the percentage of Whites over all other races, and social disorganization from the 21 counties of New Jersey between the years 2007 through 2011, for a total sample size of 105 cases of reported hate crimes. Results of the multiple linear regression analysis indicate that ethnic diversity did not significantly predict hate crimes; residential mobility and population density had positive effects on hate crime rates. Concentrated disadvantage, characterized by the number of reported unemployment rates, had a negative effect on hate crime rates. The results of the study supported social disorganization theory in reference to residential mobility and population density.
\end{abstract}

\section{Introduction}

Hate crimes in the state of New Jersey continue to be a cause for concern, despite legislation and law enforcement procedures to report and enforce hate crime laws (Berger, 2009). A factor that is unique to New Jersey's hate crimes is the high level of demographic diversity in the Northern and Central regions of the state (American Conference on Diversity, 2007). The 417 reported hate crimes in New Jersey in 2016 was a nearly 14\% increase from the previous year (O'Dea, 2018). The purpose of the present study was to determine whether there was a significant relationship between the demographic diversity and the level of hate crime rates in New Jersey based on race and ethnicity. This was accomplished by determining whether there was a significant relationship between hate crime rates and social disorganization in New Jersey from 2007 through 2011.

Social disorganization is defined as a state of society characterized by the breakdown of effective social control, resulting in a lack of functional integration and conflicting social attitudes between groups. Social disorganization includes the development of social isolation, conflict, and a sense of estrangement or alienation from the mainstream of an individual's culture. Because New Jersey is one of the most densely populated states in the United States and it is highly urbanized in the Northern and Western regions of the state (50States.com, 2015), social disorganization theory was used to examine crime rates. Social disorganization theory is defined as the inability of community members to realize common values of its residents and maintain effective social controls (Osgood \& Chambers, 2003). Social disorganization theory includes demographic diversity, population density,

This study is a result of the author's dissertation. I would like to thank Dr. Patricia Ripoll, chairperson; Dr. Gema Hernandez, committee member; and Dr. Matthew Jones, university research reviewer, under whose direction this research study was completed. I would like to thank Ms. Angela Drennen for her editorial assistance in this process. 
and urbanization, as well as concentrated disadvantage, family disruption, and residential mobility as potential influences for criminal activity.

New Jersey's hate crime rates have remained consistently high throughout the years despite the state's diverse demographic structure and hate crime reporting laws (New Jersey State Police, Uniform Crime Reporting Unit, 2011). For example, in 2010, New Jersey had the highest number of bias-related incidents with 8.58 reported hate crimes per 100,000 residents ("U.S. States With the Highest Rate," 2013). Similarly, in 2011, the state of New Jersey was among the top five states with the highest number of hate crimes (third in rank with $9 \%$ reported hate crimes and incidents) in the United States (StateMaster.com, 2011). In 2012, New Jersey ranked third with the highest number of reported hate crime rates with 5.76 incidents per 100,000 people (Katz, 2012).

New Jersey is one of the most diverse states in the United States (American Conference on Diversity, 2007). Although New Jersey is the fifth smallest state in the United States, it ranks ninth in population and is the most densely populated state with an average of 1,030 inhabitants per square mile, 13 times the national average (Some NJ Facts, 2007). This sociological and demographic composition of the state can be directly applied to the variables under social disorganization theory and may serve as the sociological indicators of the high incidence of hate crimes. Based on the statistics compiled by the Anti-Defamation League, one out of 10 hate crime incidents reported in 2008 in the United States was from New Jersey (as cited in Berger, 2009). Table 1 lists the New Jersey bias incident offenses for 2007 through 2011; although hate crimes increased between 2007 and 2008 in New Jersey, there was an overall decline from 2009 to 2011 (Anti-Defamation League as cited in Berger, 2009). However, based on the overall incidents, hate crime is still a problem in New Jersey.

Table 1. New Jersey Bias Incident Offenses

\begin{tabular}{lccccc}
\hline Bias Incident Offenses & $\mathbf{2 0 0 7}$ & $\mathbf{2 0 0 8}$ & $\mathbf{2 0 0 9}$ & $\mathbf{2 0 1 0}$ & $\mathbf{2 0 1 1}$ \\
\hline Murder manslaughter rape & 1 & - & - & - & - \\
$\begin{array}{l}\text { Robbery } \\
\text { Aggravated assault }\end{array}$ & - & - & - & - & - \\
$\begin{array}{l}\text { Burglary larceny-theft } \\
\text { simple assault }\end{array}$ & 2 & - & - & - & - \\
Fear of bodily violence & 12 & 19 & 10 & 8 & 9 \\
Arson & 5 & 3 & 2 & 1 & 1 \\
Criminal mischief & 1 & 2 & 1 & 2 & - \\
$\begin{array}{l}\text { Damage to property; threat of } \\
\text { violence }\end{array}$ & 46 & 47 & 38 & 52 & 32 \\
$\begin{array}{l}\text { Weapons offense } \\
\text { Sex offense (except rape) }\end{array}$ & 11 & 9 & 21 & 8 & 7 \\
terroristic threats trespass & 1 & 1 & 3 & 2 & 1 \\
$\begin{array}{l}\text { Disorderly conduct } \\
\text { Harassment }\end{array}$ & 268 & 358 & 263 & 287 & 176 \\
$\begin{array}{l}\text { Desecration of venerated } \\
\text { objects }\end{array}$ & 1 & 14 & 1 & 4 & - \\
All other bias incidents & 3 & - & 1 & - & - \\
\hline Note. Adapd firm & & - & 1 & 1 & - \\
\hline
\end{tabular}

Note. Adapted from the 24th annual report on bias incident offences by New Jersey State Police, Uniform Crime Reporting Unit (2011). 


\section{Social Disorganization Theory}

Social disorganization theory is focused on the changing environment and community structures that influence how different demographic groups experience difficulty and hostility in the adaptation process to other groups. In 1942, criminology researchers Shaw and McKay from the Chicago School of Criminology developed social disorganization theory. Social disorganization theory is defined as the inability of community members to realize common values of its residents and maintain effective social controls (Osgood \& Chambers, 2003). Social disorganization theorists specify that several variables, including ethnic diversity, economic status, family disruption, residential instability, population size and density, and proximity to urban areas influence a community's capacity to develop and maintain systems of social relationships, which in turn leads to criminal activity (Osgood \& Chambers, 2003).

Sampson and Wilson (1995) hypothesized that the most important process-related characteristics explaining the relationship between concentrated disadvantage and crimes are structural social disorganization and cultural social isolation. In the social disorganization perspective, Shaw and McKay (1942) focused on individuals rather than places as providing the explanation of crime and deviance. In the social disorganization theory, Sampson and Wilson (1995) argued that the separation of communities also leads to what Kornhauser (1978) defined as cultural disorganization or the decrease in cultural values in a community. Therefore, institutional instability, anonymity, distrust, poverty, and heterogeneity in urban communities hinder communication, hamper common values, and lead to delinquency or attract delinquent behavior (Sampson \& Wilson as cited in Sampson \& Bean, 2005). New Jersey's demographically divergent areas are marked by communal external factors such as different religious and social views on preconceived ideas on tradition, family, child rearing and upbringing, and other social-structure-related aspects. New Jersey is also highly diverse, densely populated, and urbanized in the Northern and Western regions of the state. In addition, New Jersey is also one of the states with the highest number of reported hate crime rates in the United States. Because of this demographic composition of the state among other factors, social disorganization theory was used to examine hate crime rates to address this social issue.

\section{Method}

In the present explanatory research study, a quantitative analysis was used to determine whether there was a relationship between demographic diversity measured using percentage non-White and hate crimes in New Jersey. The focus was on whether there was a relationship between hate crimes and social disorganization, which includes the variables of demographic diversity, concentrated disadvantage, family disruption, residential mobility, population density, and proximity to urban areas. A multiple linear regression test was conducted in analyzing a total sample of 105 cases of reported hate crimes in 21 counties representing New Jersey between the years 2007 through 2011 . Secondary data analysis was conducted using publicly available data from multiple state, federal, and local webpages. The unit of analysis was number of hate crimes.

\section{Research Questions}

Research Question 1: Is there a significant relationship between demographic diversity and the number of hate crime rates in New Jersey?

Research Question 2: Is there a significant relationship between hate crime rates and social disorganization in New Jersey? 


\section{Operationalization of Variables}

The variables in the study included demographic diversity in New Jersey, hate crime rates, and social disorganization. Social disorganization consists of six subvariables: demographic diversity, concentrated disadvantage, family disruption, residential mobility, population size or density, and proximity to urban areas of the different counties. The independent variable for Research Question 1 was race and ethnicity based on diversity, and the dependent variable was hate crime rates. The variables for Research Question 2 were hate crime rates, demographic diversity, concentrated disadvantage, family disruption, residential mobility, population density, and proximity to urban areas.

\section{Hate Crime Rates}

Hate crime rate was a continuous variable, measured by the actual hate crime statistics for race and ethnicity in the different counties for the years 2007 through 2011. Hate crime rate was a dependent variable in the regression statistical analysis.

\section{Demographic Diversity}

In the regression analysis, the study's measurement of demographic diversity was determined using the percent of non-White in the population only and measure of racial heterogeneity. The study's measurement of the race variable included the percentage of the total of each race interval/ratio. Although there were numerous alternate measurements for diversity/heterogeneity that could have been chosen for the study, this method was chosen because it represents the composition of race in each county while controlling for the composition of other races. For this research study, there was adequate control in the model used for the analysis, containing a large enough sample size as required for the predictor variables.

\section{Concentrated Disadvantage}

Concentrated disadvantage was a continuous variable measured by the actual number of unemployment rates in the different counties for the years 2007 through 2011. Concentrated disadvantage was included in the regression statistical test for the analysis of the second research question.

\section{Family Disruption}

Family disruption was a continuous variable that was measured by the estimated number of widowed, divorced, and separated rates combined, based on a population of 15 years of age and older, in the different counties for the years of 2007 through 2011. Family disruption was included in the regression statistical test for the analysis of the second research question.

\section{Residential Mobility}

Residential mobility was a continuous variable, measured by the total estimated number of residents age 1 year and older who moved within the same county, moved from a different county in the same state, moved from different state, or moved from abroad between 2007 and 2011. Residential mobility was included in the regression statistical test for the analysis of the second research question.

\section{Population Size of Density}

Population size of density was a continuous variable using the population size per area for each of the different counties. Population size of density was included in the regression statistical test for the analysis of the second research question. This remained constant throughout the selected period of 2007 through 2011. 


\section{Proximity to Urban Areas}

For the measurement of the proximity to urban areas variable, a continuous variable was used that was the closest distance from a county's border or boundary line to an urban area. Due to the small size of New Jersey and because most counties in the state are urbanized, proximity to urban areas for each respective county was measured based on a county's closest proximity to the New York City or Philadelphia metropolitan areas. Using the U.S. Census' (1996) New Jersey Metropolitan Areas, Counties, and Central Cities map, the computation for the distance was started on the border or boundary line of each county. Then I measured northeast for those counties closest to the New York City metropolitan areas. Lastly, the measurement ended at the beginning of the border or boundary line of the New York City metropolitan area and a county's boundary or borderline measuring west for those counties closest to the Philadelphia metropolitan areas. The calculation focused on the distance in miles identified on the respective map scale using the proportion formula. Proximity to urban areas was included in the regression statistical test for analysis of the second research question.

\section{Data Collection}

This research study was based on a quantitative research design, which consists of the data for the time frame of 2007 through 2011. The compilation for the data was from federal and state sources. New Jersey's demographics are based on data retrieved from the U.S. Census Bureau (years 2007 through 2011) on ethnic diversity; family disruption characterized by estimated widowed, divorced, and separated rates combined; population 15 years of age and older; residential mobility characterized by the total estimate number of residents; and population age 1 and older who moved within the same county, moved from different county same state, moved from different state, and moved from abroad. The next set of data for hate crime rates was based on race and ethnicity and was derived from the U.S. Department of Justice, Federal Bureau of Investigation's Criminal Justice Information Services Division, Uniform Crime Reports, Hate Crime Statistics, New Jersey Hate Crime Incidents per Bias Motivation and Quarter by State and Agency. The retrieval of the concentrated disadvantage characterized by the actual number of unemployment rates was from the U.S. Bureau of Labor Statistics.

The retrieval of the population size of density data was from the "New Jersey Population Density County Rank" (2014), an online source that revealed the population density for each of the 21 counties of New Jersey. The proximity to urban areas data was retrieved from the mapping calculation standard from the U.S. Department of Commerce, Economics and Statistics Administration (U.S. Census Bureau, 1996), and U.S. Census Bureau (years 2007 through 2011). Population size of density and proximity to urban areas were the only two variables, which remained constant for the period 2007 through 2011 (please see Appendix).

\section{Instrument Selection}

For this study, I used the secondary data and information retrieved from the publicly available data outlined earlier. The analysis also includes how the ethnically diverse areas of the different counties in New Jersey affected hate crimes with the percentage of non-Whites through a multiple linear regression statistical test to address the first research question. The relationship between hate crimes and social disorganization in New Jersey was also analyzed with a multiple linear regression statistical test to address Research Question 2. The unit of analysis for the study was hate crimes and the data analysis was on race and ethnicity. Because of the quantitative nature of this study that encompassed data for all 21 counties representing the state of New Jersey, and 105 cases based 
on the data sets, the statistical tests outlined provided the link on the variables in reference to their location.

These methods provided adequate information on the relationship between demographic diversity and the impact of hate crimes in New Jersey. Additionally, the research provided information on the social and economic factors as outlined under social disorganization theory that may have an influence on hate crimes. The exploration of additional patterns and trends in targeted areas involving hate crimes and hate incidents are available.

\section{Data Analysis}

To summarize the data, the descriptive statistics of the study variables of demographic diversity; hate crime rates; and the social disorganization variables of ethnic diversity, concentrated disadvantage, family disruption, residential mobility, population size of density, and proximity to urban areas of the different counties were analyzed. The continuous variables of hate crime rates; the social disorganization subvariables of demographic diversity, concentrated disadvantage, family disruption, and residential mobility; population size of density; and proximity to urban areas were summarized using the central tendency measures of means and standard deviation, whereas the categorical study variables were summarized using frequency and percentage summary.

The purpose for Research Question 1 was to examine whether there was a significant relationship between the demographic diversity and the number of hate crime rates in New Jersey. In the multiple linear regression analysis, the relationship of each of the percentages data of composition in the 21 different types of race/ethnicity of the different counties to hate crime rates was examined. A regression analysis was conducted to determine the influences of each of the 21 different types of race/ethnicity to hate crime rates statistically. The identification of the independent variable was demographic diversity, and the dependent variable was hate crime rates.

In the linear regression analysis, the main effects of each of the race/ethnicity composition to the dependent variable of hate crime rates were examined. The race/ethnicity composition percentage in the different counties was measured to ascertain whether it had an effect on hate crime rates of the different counties in a single regression model.

For Research Question 2, the purpose was to examine whether there was a significant relationship between hate crimes and social disorganization subvariables of ethnic diversity as measured by the demographically divergent areas, concentrated disadvantage, family disruption, residential mobility, population size of density, and proximity to urban areas of the different counties in New Jersey. The relationship between these variables was examined using a multiple linear regression. A regression analysis was used to determine the significant influence of the different measures of social disorganization to hate crime rates in New Jersey. As stated previously, social disorganization consists of six subvariables of demographic diversity, concentrated disadvantage, family disruption, residential mobility population size or density, and proximity to urban areas of the different counties.

\section{Results}

\section{Research Population and Summary of the Cases of Sample}

The sample of the study consisted of 105 cases based on the data sets that contained the statistical data of reported hate crimes of each county in New Jersey. The cases contained 21 measurement 
observations for each of the study variables of hate crime rates and the six social disorganization variables of demographic diversity: concentrated disadvantage, family disruption, residential mobility, population size or density, and proximity to urban areas of the different counties for each year from 2007 to 2011 . The measurement for each of the study variables was over 5 years. The research population for this quantitative research study included all 21 counties representing the State of New Jersey: Atlantic, Bergen, Burlington, Camden, Cape May, Cumberland, Essex, Gloucester, Hudson, Hunterdon, Mercer, Middlesex, Monmouth, Morris, Ocean, Passaic, Salem, Somerset, Sussex, Union, and Warren. For the purpose of this study, the collection of the statistical data was from the population of each county in reference to reported hate crimes, ethnic diversity, and all the variables under social disorganization theory. The descriptions of the cases by county and by years are available in Tables 2 and 3. Tables 2 and 3 summarize the total number of data while the percent was the ratio of the frequency by 100 to determine the fraction of composition in the cases. For the frequency and percentage summaries of the description of the cases of sample, for each of the years (2007 through 2011), there were 21 different cases of the data of the study variables. Thus, 21 frequencies represented $20 \%$ out of the $100 \%$. For the frequency and percentage summaries of the description of the cases of sample by county, there were five different cases or frequency which represented $4.8 \%$ out of the $100 \%$.

Table 2. Calculated Distance of Counties Closest to New York City or Philadelphia Metropolitan Areas

\begin{tabular}{lccc}
\hline County & Closest Metro Area & Measurement (in.) & Distance (mi.) \\
\hline Atlantic & Philadelphia & 1.25 & 22.5 \\
Bergen & New York City & 1.14 & 1.1 \\
Burlington & Philadelphia & 1.14 & 1.1 \\
Camden & Philadelphia & 1.14 & 1.1 \\
Cape May & Philadelphia & 2.06 & 37.1 \\
Cumberland & Philadelphia & 1.12 & 20.2 \\
Essex & New York City & 0.25 & 4.5 \\
Gloucester & Philadelphia & 1.14 & 1.1 \\
Hudson & New York City & 1.14 & 1.1 \\
Hunterdon & Philadelphia & 0.75 & 13.5 \\
Mercer & Philadelphia & 0.62 & 11.2 \\
Middlesex & New York City & 0.5 & 9 \\
Monmouth & New York City & 0.31 & 5.6 \\
Morris & New York City & 0.81 & 14.6 \\
Ocean & Philadelphia & 1.12 & 20.2 \\
Passaic & New York City & 0.37 & 6.7 \\
Salem & Philadelphia & 0.56 & 10.1 \\
Somerset & New York City & 1 & 18 \\
Sussex & New York City & 1.5 & 27 \\
Union & New York City & 0.31 & 5.6 \\
Warren & Philadelphia & 1.69 & 30.4 \\
\hline
\end{tabular}

\section{Calculation of Proximity to Urban Areas Variable}

Proximity to urban areas was calculated using the proportion formula based on the distance in miles as identified on the map scale in the New Jersey Metropolitan Areas, Counties, and Central Cities map (U.S. Census, 1996). The proportion formula used is from Dance and Sandefur's (2004) guide on how to calculate distance on a map using a proportion formula. The measurement for the distance computation was focused on the border or boundary line of each county measuring northeast for 
those counties closest to the New York City metropolitan area and ended at the beginning of the border or boundary line of the New York City metropolitan area. The measurement for distance was by a county's boundary or borderline measuring west for those counties closest to the Philadelphia metropolitan areas and ended at the beginning of the border or boundary line of the Philadelphia metropolitan area.

The proportion formula used to calculate proximity to urban areas was as follows:

$$
\frac{1}{18}=\frac{\# \text { of measured mi. }}{x}
$$

See Table 2 for the results of each of the calculated distance of each county closest to the identified urban or metropolitan area.

Table 3. Descriptive Statistics Summaries of Hate Crime Rates and Social Disorganization Data

\begin{tabular}{|c|c|c|c|c|c|}
\hline \multirow[b]{2}{*}{ Study Variables } & \multirow[b]{2}{*}{$N$} & \multirow[b]{2}{*}{$M$} & \multirow[b]{2}{*}{$S D$} & \multicolumn{2}{|c|}{$95 \%$ CI for $B$} \\
\hline & & & & Lower & Upper \\
\hline Hate crime rates & 105 & 15.28 & 19.04 & 12.94 & 20.61 \\
\hline $\begin{array}{l}\text { Concentrated } \\
\text { disadvantage }\end{array}$ & 105 & 7.78 & 2.74 & 7.05 & 8.14 \\
\hline Family disruption & 105 & 17.20 & 1.99 & 0.17 & 0.17 \\
\hline Residential mobility & 93 & $\begin{array}{c}447,762.8 \\
3\end{array}$ & $\begin{array}{c}230,093.7 \\
5\end{array}$ & $\begin{array}{c}403,992.4 \\
9\end{array}$ & $\begin{array}{c}494,221.3 \\
3\end{array}$ \\
\hline $\begin{array}{l}\text { Population size of density } \\
\left(\mathrm{mi}^{2}\right)\end{array}$ & 105 & $1,943.21$ & $2,458.43$ & $1,679.16$ & $2,749.33$ \\
\hline $\begin{array}{l}\text { Proximity to urban areas/ } \\
\text { distance (mi.) }\end{array}$ & 105 & 12.46 & 10.41 & 9.02 & 12.72 \\
\hline
\end{tabular}

Note. CI = confidence interval. $N$ represents the total number of the data cases.

\section{Descriptive Statistics Analysis of Study Variables}

Table 3 summarizes the descriptive statistics of the continuous measured study variables of hate crime rates and social disorganization variables. Social disorganization variables included the six subvariables of demographic diversity (percentage of non-White), concentrated disadvantage (characterized by unemployment rates), family disruption (characterized by estimated widowed, divorced, and separated rates combined), residential mobility, population size or density, and proximity to urban areas of the different counties. The descriptive statistics included the measures of central tendency of mean and standard deviations.

The study consisted of 105 different cases of the study variables of hate crime rates and the six social disorganization variables of demographic diversity, concentrated disadvantage, family disruption, population size or density, and proximity to urban areas. However, the social disorganization variable of residential mobility had only a total of 93 , as there were only 93 different cases for this variable.

The mean hate crime rate of the different counties was 15.28 , with the highest hate crime rate among the counties at 113 and the lowest was 0 . The mean concentrated disadvantage of the different counties was $7.78 \%$, with the highest number of concentrated disadvantages among the 
counties at $13.60 \%$ and the lowest was at $2.90 \%$. The mean family disruption of the different counties was $17.20 \%$, with the highest number of family disruption among the counties at $21.90 \%$ and the lowest was at $12.40 \%$. The mean residential mobility of the different counties was at $447,762.83$, with the highest number of residential mobility among the counties at 901,401 and the lowest was at 483. The mean population size of density of the different counties was at $1,943.21 \mathrm{mi}^{2}$, with the highest number of population size of density among the counties at 10,178.70 mi. ${ }^{2}$ and the lowest was at $156.80 \mathrm{mi}^{2}$ Lastly, the mean proximity to urban areas of the different counties was $12.46 \mathrm{mi}$., with the highest number of proximities to urban areas among the counties at $37.10 \mathrm{mi}$. and the lowest was at $1.10 \mathrm{mi}$. The sample size was calculated based on Cohen's effect size, the level of significance (alpha level), and the power of the study. In the computation, the use of a regression analysis with six predictors was considered, with a power of 0.80 , medium effect size (0.15), and a level of significance of .05 .

Table 4 summarizes the descriptive statistics data for demographic diversity. This contains the composition of the different race/ethnicity in the different counties. The top three highest number of races/ethnicities in the different counties were Caucasian $(M=74.16 \%)$, Hispanic or Latino $(M=$ $14.58 \%)$, and Black or African American $(M=12.32 \%)$. There were significant numbers of Asian $(M=$ $6.11 \%)$, Asian Indian $(M=7.34 \%)$, Caucasian and Black or African American $(M=5.15 \%)$, and other Hispanic or Latino $(M=6.83 \%)$ races with percentages greater than $5 \%$.

Table 4. Descriptive Statistics Summaries of Demographic Diversity Data

\begin{tabular}{|c|c|c|c|c|c|}
\hline \multirow[b]{2}{*}{ Race/Ethnicity } & \multirow[b]{2}{*}{$N$} & \multirow[b]{2}{*}{$M$} & \multirow[b]{2}{*}{$S D$} & \multicolumn{2}{|c|}{$95 \% \mathrm{CI}$} \\
\hline & & & & Lower & Upper \\
\hline Caucasian & 104 & 74.16 & 13.64 & 70.98 & 76.54 \\
\hline Black or African American & 104 & 12.32 & 9.05 & 10.71 & 14.32 \\
\hline American Indian and Alaska Native & 103 & 0.27 & 0.29 & 0.21 & 0.31 \\
\hline Asian & 104 & 6.11 & 5.12 & 5.29 & 7.38 \\
\hline Asian Indian & 101 & 7.34 & 13.04 & 5.16 & 10.19 \\
\hline Chinese & 101 & 4.45 & 8.89 & 2.99 & 6.42 \\
\hline Filipino & 101 & 3.95 & 8.15 & 2.59 & 5.74 \\
\hline Japanese & 101 & 0.39 & 0.93 & 0.23 & 0.60 \\
\hline Korean & 101 & 2.12 & 5.12 & 1.29 & 3.30 \\
\hline Vietnamese & 101 & 0.97 & 2.88 & 0.51 & 1.62 \\
\hline Other Asian & 101 & 1.40 & 2.64 & 0.95 & 1.98 \\
\hline $\begin{array}{l}\text { Native Hawaiian and Other Pacific } \\
\text { Islander }\end{array}$ & 104 & 0.02 & 0.05 & 0.01 & 0.03 \\
\hline Caucasian and Black or African American & 103 & 5.15 & 11.27 & 3.39 & 7.92 \\
\hline $\begin{array}{l}\text { Caucasian and American Indian and } \\
\text { Alaska Native }\end{array}$ & 103 & 1.66 & 3.76 & 1.07 & 2.57 \\
\hline Caucasian and Asian & 103 & 3.64 & 8.89 & 2.20 & 5.81 \\
\hline $\begin{array}{l}\text { Black or African American and American } \\
\text { Indian and Alaska Native }\end{array}$ & 103 & 1.23 & 3.66 & 0.62 & 2.05 \\
\hline Hispanic or Latino & 105 & 14.58 & 10.17 & 12.89 & 16.96 \\
\hline Mexican & 105 & 2.21 & 2.06 & 1.82 & 2.61 \\
\hline Puerto Rican & 105 & 4.37 & 3.30 & 3.76 & 4.99 \\
\hline Cuban & 105 & 0.74 & 1.06 & 0.56 & 1.00 \\
\hline Other Hispanic or Latino & 105 & 6.83 & 6.65 & 5.85 & 8.53 \\
\hline
\end{tabular}

Note. CI = confidence interval. 


\section{Regression Results for Research Question 1}

The regression results determined the relationship of the independent variables of demographic diversity to the dependent variable of hate crime rates. In the regression results, demographic diversity measured using percentage non-White in the different counties had a significant influence on hate crime rates. The level of significance used for the regression model was .05. Independent variables have a significant influence if the $p$ values are equal or less than the level of significance value of .05. Table 5 summarizes the regression results revealing the influence of the demographic diversity measure of percentage non-Whites to hate crime rates in New Jersey.

Table 5. Regression Results of Influence of Demographic Diversity to Hate Crime Rates

\begin{tabular}{|c|c|c|c|c|c|c|}
\hline \multirow[b]{2}{*}{ Study Variables } & \multirow[b]{2}{*}{$B$} & \multirow[b]{2}{*}{$S E$} & \multicolumn{2}{|c|}{$\begin{array}{l}\text { Collinearity } \\
\text { Statistics }\end{array}$} & \multicolumn{2}{|c|}{$95 \%$ CI for $B$} \\
\hline & & & Tolerance & VIF & $\begin{array}{l}\text { Lower } \\
\text { Bound }\end{array}$ & $\begin{array}{l}\text { Upper } \\
\text { Bound }\end{array}$ \\
\hline (Constant) & 14.89 & 2.75 & & & 9.43 & 20.35 \\
\hline $\begin{array}{l}\text { Demographic divergence of } \\
\text { areas (\% of non-White) }\end{array}$ & 0.03 & 0.11 & 1.00 & 1.00 & -0.19 & 0.24 \\
\hline
\end{tabular}

Note. VIF = variance inflation factor; CI = confidence interval. $F(1,102)=0.06, p=.81$ (significant influence at the .05 level of significance), $R^{2}=0.001$, Durbin-Watson $=0.46, N=103$.

The model fit in terms of $R^{2}$ of the generated linear regression model was 0.001 , which indicates that the measure of demographic diversity in New Jersey accounted for only $0.01 \%$ of the variance in the prediction of number of hate crime rates and the model fit was not acceptable. This means that the measure for the independent variable of demographic diversity had a low combined effect size on hate crime rates. In other words, for this research question and hypothesis, the focus was on determining the effects of demographic diversity as measured by the demographic diversity measure of percentage non-White. There was adequate power in the model, which contained a large enough sample size required for the predictor variables. The results of the linear regression, $F(1,102)=0.06$, $p=.81$ ) was nonsignificant. Thus, the overall effect for the independent variable of demographic diversity of percentage non-Whites on hate crime rates was nonsignificant.

In the regression results, the demographic diversity measures of percentage of non-White only, $t(103)=0.25, p=.81$, did not significantly influence hate crime rates in New Jersey. Therefore, racial diversity had no relationship to the dependent variable of hate crime rates. The evidence for this finding is on the nonsignificant analysis of variance and the coefficient for that predictor in the regression model. Thus, this signified that there is no significant relationship between demographic diversity and hate crime rates.

First, an analysis for the test of linearity, test for independence, and test of homogeneity of variance was conducted. The summary of the test result is in Table 6 . Table 6 reveals that the dependent variable of hate crime rates was not linearly related with the independent variable of demographic diversity measure of percentage non-Whites. Thus, there was a violation in the assumption of linear relationships between the independent and dependent variable in this regression analysis.

Second, the study's analysis was based on the investigation of the test for independence of error using the Durbin-Watson statistic. The Durbin-Watson test produced a statistic of 0.46, indicating that this model suffered from serial correlation. This indicates that there was a violation on the assumption of independence of errors in the regression model. 
Third, the assumption of homoscedasticity of the variance of the model for the prediction of the hate crime rates with the measure of the percentage non-Whites only to represent demographic diversity were investigated using the scatterplots of the standardized residuals and the regression standardized predicted value. These results of the analysis are available in Figure 1, which represents the plot of standardized residuals versus regression standardized predicted value of prediction of hate crime rates by different demographic diversity rates. The pattern of the data points in Figure 1 is scattered and not narrow, which indicates that the different cases show signs of mild heteroscedasticity. Thus, there was slight violation in the assumption of homoscedasticity of the variance in the regression results.

Table 6. Test of Deviation From Linearity of the Relationship Between Demographic Diversity and Hate Crime Rates

\begin{tabular}{lccccc}
\hline & $\begin{array}{c}\text { Sum of } \\
\text { Rquares }\end{array}$ & $\boldsymbol{d} \boldsymbol{f}$ & $\begin{array}{c}\text { Mean } \\
\text { Square }\end{array}$ & $\boldsymbol{F}$ & $\boldsymbol{p}$ \\
\hline $\begin{array}{l}\text { Demographic } \\
\text { Divergence of areas } \\
\text { (\% of non-White) }\end{array}$ & $36,510.87$ & 85 & 429.54 & 7.12 & $.00^{*}$ \\
\hline * Significant influence at the .05 level of significance.
\end{tabular}

The regression results to determine the relationship of the independent variables of social disorganization to the dependent variable of hate crime rates in New Jersey. In the regression results, the six subvariables of social disorganization of demographic diversity (measured using the percentage of non-White only), concentrated disadvantage, family disruption, residential mobility, population size of density, and proximity to urban areas of the different counties had a significant influence on hate crime rates in New Jersey. Table 7 summarizes the regression results displaying the influence of each of the six subvariables of social disorganization to hate crime rates in New Jersey.

Table 7. Regression Results of Influences of Six Subvariables of Social Disorganization to Hate Crime Rates

\begin{tabular}{|c|c|c|c|c|c|c|}
\hline \multirow[b]{2}{*}{ Study Variables } & \multirow[b]{2}{*}{$\begin{array}{c}\text { Unstandardized } \\
\text { Coefficient } B \\
\end{array}$} & \multirow[b]{2}{*}{$S E$} & \multicolumn{2}{|c|}{$\begin{array}{l}\text { Collinearity } \\
\text { Statistics }\end{array}$} & \multicolumn{2}{|c|}{$95 \%$ CI for $B$} \\
\hline & & & Tolerance & VIF & $\begin{array}{l}\text { Lower } \\
\text { Bound }\end{array}$ & $\begin{array}{l}\text { Upper } \\
\text { Bound }\end{array}$ \\
\hline (Constant) & -6.34 & 15.93 & & & -38.00 & 25.32 \\
\hline $\begin{array}{l}\text { Demographic divergence } \\
\text { of areas (\% of non-White) }\end{array}$ & -0.19 & 0.11 & 0.63 & 1.59 & -0.42 & 0.03 \\
\hline $\begin{array}{l}\text { Concentrated } \\
\text { disadvantage }\end{array}$ & $-2.22^{*}$ & 0.78 & 0.62 & 1.63 & -3.76 & -0.68 \\
\hline Family disruption & 2.06 & 1.13 & 0.57 & 1.75 & -0.18 & 4.31 \\
\hline Residential mobility & $0.00005^{*}$ & 0.00 & 0.52 & 1.91 & 0.00 & 0.00 \\
\hline $\begin{array}{l}\text { Population size of density } \\
\left(\mathrm{mi} .^{2}\right)\end{array}$ & $0.004^{*}$ & 0.00 & 0.60 & 1.66 & -0.01 & 0.00 \\
\hline $\begin{array}{l}\text { Proximity to urban } \\
\text { areas/distance (mi.) }\end{array}$ & -0.46 & 0.26 & 0.51 & 1.95 & -0.97 & 0.04 \\
\hline
\end{tabular}




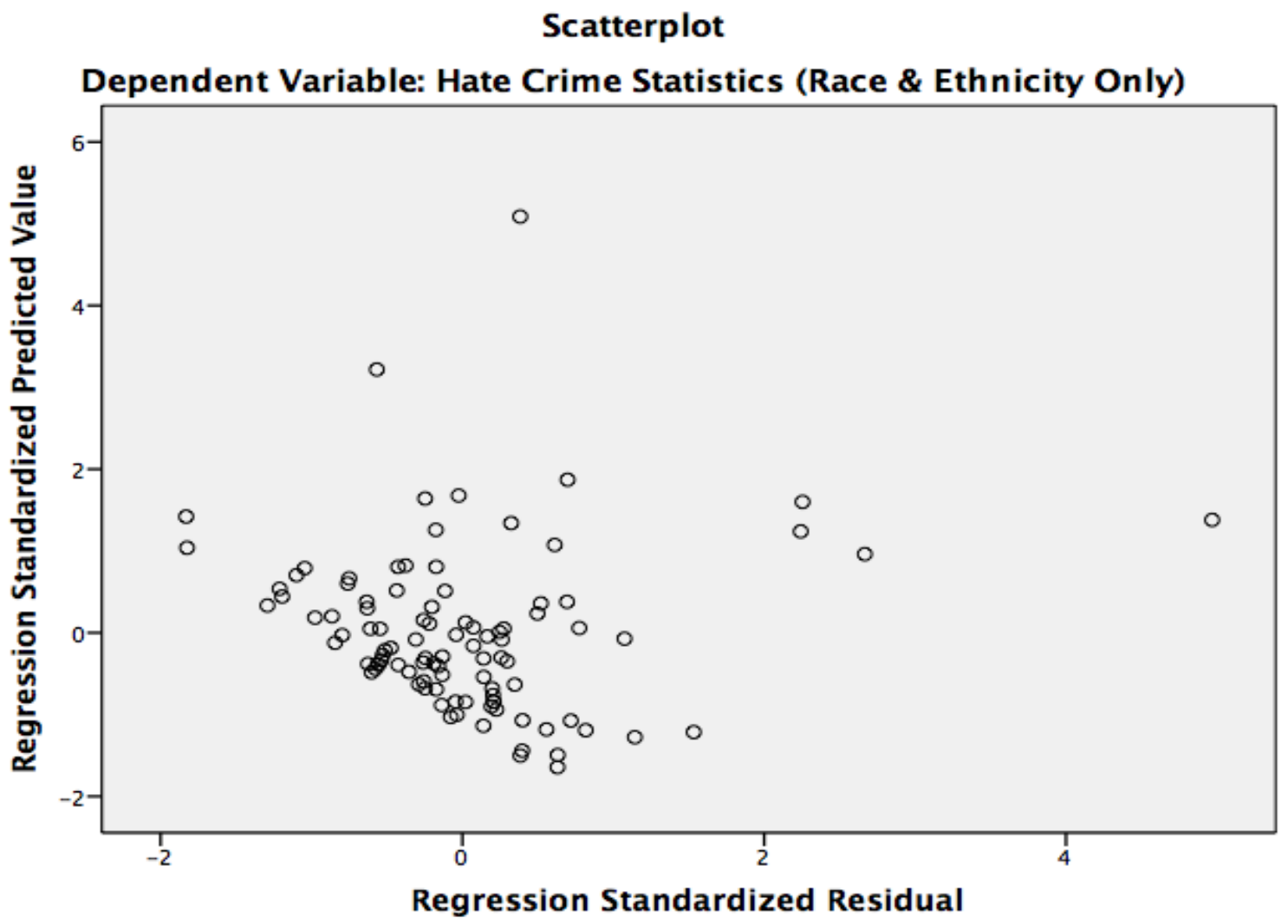

Figure 1. Plot of Standardized Residuals Versus Regression Standardized Predicted Value of Prediction of Hate Crime Rates by Different Demographic Diversity Rates

\section{Regression Results for Research Question 2}

The model fit in terms of $R^{2}$ of the generated linear regression model was 0.40 , which indicates that six subvariables of social disorganization accounted for $40 \%$ of the variance in the prediction of number of hate crime rates in New Jersey. The model fit was acceptable. This means that the six subvariables of social disorganization had a moderate combined effect on hate crime rates. The results of the multiple linear regression, $F(6,86)=9.69, p<.001$, were significant, which indicates that the overall effects of the six subvariables of social disorganization on hate crime rate was significant.

The regression results indicate which among the six subvariables of social disorganization had a significant influence on hate crime rates in New Jersey. The results revealed that the individual effects of the subvariables under social disorganization of concentrated disadvantage, $t(96)=-2.86, p$ $=.01$, residential mobility, $t(96)=4.96, p<.001$, and population size of density, $t(96)=-4.49, p<$ .001 , had a significant influence on hate crime rates in New Jersey. Based on the unstandardized beta coefficient, residential mobility $(B=0.00005)$ and population size of density $(B=0.004)$ had positive influences, whereas concentrated disadvantage $(B=-2.22)$ had negative influence or was negatively related to hate crime rates. The subvariables of ethnic diversity, family disruption, and proximity to urban areas did not have a significant influence or effect on hate crime rates. 
These results indicate that there is a significant relationship between hate crime rates and social disorganization in New Jersey. The variables of concentrated disadvantage, residential mobility, and population size of density had significant influences on hate crime rates. The significant relationship was only in reference to the residential mobility and population size of density variables. This is because the results of the regression revealed the effect of the subvariable of concentrated disadvantage, which had the largest effect, based on the unstandardized $B$ coefficient, and had a significant negative effect on hate crime rates.

The collinearity statistics of tolerance and variance inflation factor figures to test for multicollinearity for each of the six subvariables of the independent variable of social disorganization in New Jersey on the dependent variable of hate crime rates are available in Table 7 . The tolerance statistics of all the six subvariables of social disorganization in New Jersey were all greater than 0.10 . The variance inflation factor values of all six subvariables of social disorganization in New Jersey were all less than 2.5. This means that the six subvariables of the independent variable of social disorganization in New Jersey were not multicollinear in predicting hate crime rates.

First, there was the assumption that the relationships between the independent and the dependent variables should be linear. The application of the test of linearity was using the test of deviation from linearity. The summary of the test result is in Table 8 . There is a linear relationship between the independent variable and the dependent variable if the $p$ values are greater than the level of significance value of .05. By examining Table 8, there was a linear relationship between concentrated disadvantage and hate crime rates, $F(61)=0.68, p=.92$, and between family disruption and hate crime rates, $F(56)=0.88, p=.68$, only. These were the only $p$ values greater than the level of significance of .05. On the other hand, the independent variables of demographic divergence of areas, $F(85)=7.12, p<.001$, population size of density, $F(19)=35.48, p<.001$, and proximity to urban areas/distance, $F(13)=4.06, p<.001$, were not linearly related with hate crime rates. Thus, there was a violation in the assumption of linear relationships between the independent and dependent in this regression analysis.

Table 8. Test of Deviation From Linearity of the Relationships of Six Subvariables of Social Disorganization With Hate Crime Rates

\begin{tabular}{|c|c|c|c|c|c|}
\hline Study Variables & $\begin{array}{c}\text { Sum of } \\
\text { Squares }\end{array}$ & $d f$ & Mean Square & $\boldsymbol{F}$ & $p$ \\
\hline $\begin{array}{l}\text { Demographic divergence } \\
\text { of areas (\% of non-White) }\end{array}$ & $36,510.87$ & 85 & 429.54 & 7.12 & .00 \\
\hline Concentrated disadvantage & $17,571.85$ & 61 & 288.06 & 0.68 & $.92 *$ \\
\hline Family disruption & $19,125.71$ & 56 & 341.53 & 0.88 & $.68^{*}$ \\
\hline \multicolumn{6}{|l|}{ Residential mobilitya } \\
\hline $\begin{array}{l}\text { Population size of density } \\
\text { (mi. }{ }^{2} \text { ) }\end{array}$ & $33,452.03$ & 19 & $1,760.63$ & 35.48 & .00 \\
\hline $\begin{array}{l}\text { Proximity to urban } \\
\text { areas/distance (mi.) }\end{array}$ & $12,850.05$ & 13 & 988.47 & 4.06 & .00 \\
\hline
\end{tabular}

Second, the Durbin-Watson statistic tested for independence of error. The Durbin-Watson test (0.78) conducted for the regression results to determine the relationship of the independent variables of the six social disorganization variables to the dependent variable of hate crime rates in New 
Jersey was less than 1 . There was a violation in the assumption of independence of errors. This means that there was a correlation between one observation and the errors of any other observation.

Third, the assumption of homoscedasticity of the variance of the model for the prediction of the hate crime rates with the six social disorganization variables was investigated using the scatterplots of the standardized residuals and the regression standardized predicted value. These are available in Figure 2. The pattern of the data points in Figure 2 is scattered and not narrow, which indicates that the cases are not showing signs of mild heteroscedasticity. Thus, there was a slight violation in the assumption of homoscedasticity of the variance in the regression results.

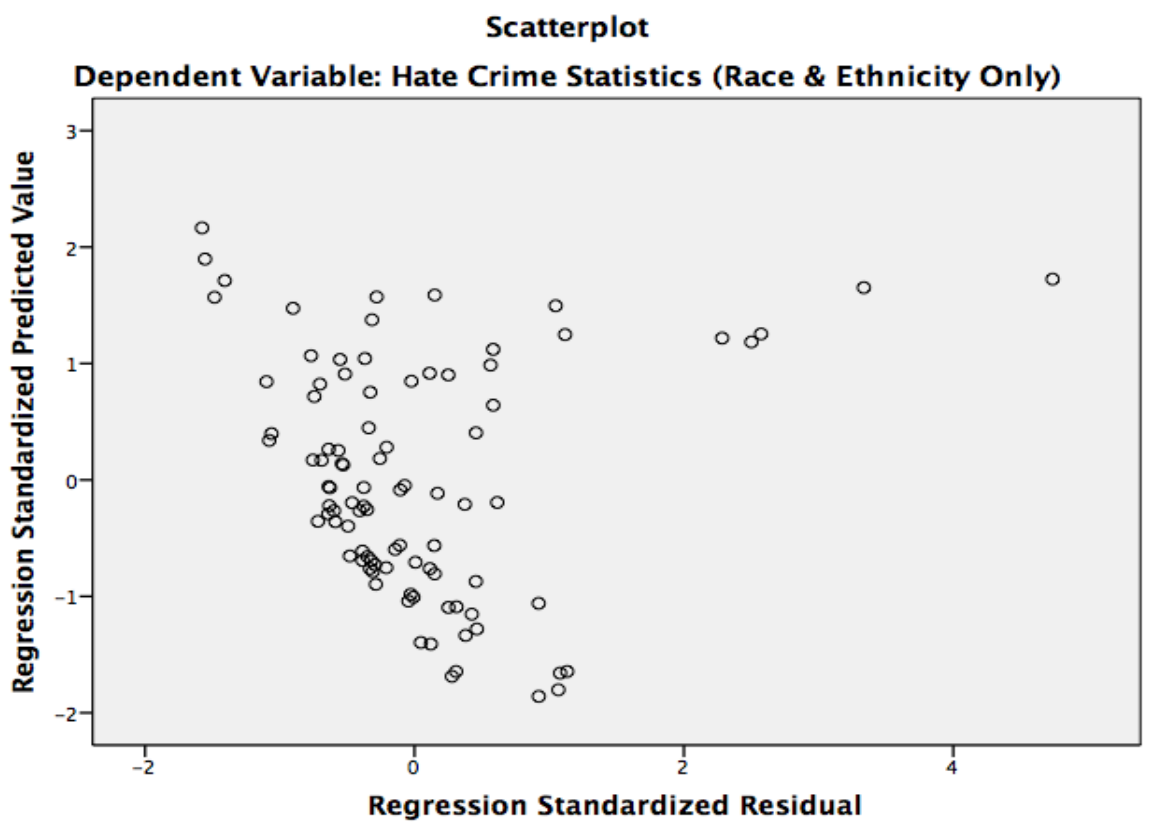

Figure 2. Plot of Standardized Residuals Versus Regression Standardized Predicted Value of Prediction of Hate Crime Rates by Six Subvariables of Social Disorganization

\section{Discussion}

The current study was the first in which all 21 counties representing the state of New Jersey (as opposed to a sample of the population) were included in the examination of diversity as a possible relational causal factor to hate crime rates using social disorganization theory. In addition, this study was also the first research study where all six variables identified in social disorganization theory were used to determine the demographic, economic, and/or social characteristics as relational factors to the problem of hate incidence. Based on the extensive literature review conducted of similar studies, other researchers implemented only two or four, but not all six variables of social disorganization theory. Including all 21 counties of the state in conjunction with implementing all six variables under social disorganization theory provides the reader with a holistic interpretation of the study. Although the hypothesis was that these variables are linked and/or associated with high hate crime rates in New Jersey, there was no presumption made that these characteristics are the only 
links to this problem. However, the references to the historical and current demographic facts relevant to this phenomenon are explained in the literature.

Previous research has shown that hate crime is more likely to occur in areas with a concentrated disadvantage and residential turnover (Grattet, 2009). Grattet used data, bias crime, as well as other kinds of criminal offenses (mainly robbery, assault, and vandalism) to research the similarities and differences between hate crimes and regular crimes in the diverse city of Sacramento, California. Similar to the current study, Grattet used social disorganization theory as well as the defended neighborhoods perspective and combined the concepts of social ecology of crime with intergroup conflict and neighborhood ethnic transition. The results of Grattet's study revealed that ethnic conflict is likely to take place in settings where there is little or no aptitude for informal social control to intervene in actions between different groups. The results also revealed that socially disorganized communities are very likely to erupt in crime and violence, and even when poverty and residential turnover remain unchanged, bias incidents are still affected by demographic dynamics or the "neighborhood defense" (Grattet, 2009).

The current study is also supported in its findings on residential mobility and hate crimes, though results may differ in some regards. Kubrin (2000) examined the relationship between racial heterogeneity and crime within neighborhoods in Seattle, Washington, in 1980 and 1990, ascertaining whether changes in levels of racial heterogeneity are associated with changes in the crime rates over the 10-year period. Based on the results of the study, racial heterogeneity was shown to be the strongest predictor of violent crime in Seattle (Kubrin, 2000). However, dynamic measures of other socioeconomic and demographic variables, such as percent Black, poverty, unemployment, divorce, and young males, were not positively associated with changes in the violent crime during the 10-year period. On the other hand, the variable measuring social mobility was significant; it was only weakly associated with changes in the violent crime index (Kubrin, 2000). Unlike Kubrin's study, the results for the present study did not reveal a significant influence between demographic diversity and hate crime rates. As mentioned previously, concentrated disadvantage was found to have a significant negative effect on hate crime rates; additionally, there was no significant relationship between family disruption (in Kubrin's study it was characterized by divorce) and hate crime rates. Similar to Kubrin's study, however, this study revealed a significant relationship between hate crimes and residential or social mobility.

Another study that supported the current study's findings on residential mobility was conducted by Gainey, Sun, and Triplett (2004), who used data from 36 neighborhoods from seven United States cities to examine extensions of Sampson and Groves' (1989) model of social disorganization theory in its effectiveness in transmitting the effects of neighborhood structural characteristics on assault rather than on robbery. Based on the findings of the research, residential mobility, racial heterogeneity, and family disruption exert significant direct effects on robbery (Gainey et al., 2004). Similarly, this current study found a significant relationship between residential mobility and hate crime rates. However, the results of the current study did not show a significant relationship between racial heterogeneity or family disruption and hate crimes.

The findings for this study provide support for the prevailing theory of social disorganization on the occurrence of hate crimes in New Jersey. In this study, the demographic, social, and economic factors that contribute to social disorganization were examined. Through the results of the study, it was determined that ethnic diversity was not a predicting factor of a high level of hate crime rates, as addressed by Research Question 1. Based on the results of the study, residential mobility, population 
density, and concentrated disadvantage within a community are the predicting factors of the incidence of hate crimes in New Jersey, as addressed by Research Question 2.

Other research supports the current study's findings on concentrated disadvantage. For example, Stacey (2010) examined the relationship between the demographic shifts and bias crime trends from 2000 to 2007. Population average panel models were used to estimate changes over time and across place in the number of bias crimes in a state as a function of changing demographic, economic, and political conditions (Stacey, 2010). The results revealed that there is a disparity in anti-minority hate crimes across states and over time. These patterns may be explained by the change in demographics and political mobilization of minority groups. The results for economic threat indicator did not support a relationship between economic conditions and hate crimes in a state (Stacey, 2010). The results also revealed that urban populations, while significant, do not reduce the effect of minority or political threat on hate crime (Stacey, 2010). Additionally, states with less poverty overall had a higher level of hate crimes (Stacey, 2010). Similar to this study, the current study did not reveal a significant relationship between concentrated disadvantage or economic threat or proximity to urban areas or urban populations and hate crimes. In fact, both Stacey's study and the current study indicated that concentrated disadvantage had a significant inverse effect on hate crime rates.

\section{Summary of Results}

For Research Question 1, a linear regression analysis was conducted using demographic diversity measured using the percentage of non-Whites in the different counties as the independent variables and hate crime rates as the dependent variable. The results of the regression analysis indicate that the proposed model was not statistically significant, wherein the demographic diversity that measured the percentage of non-White only accounted for only $0.1 \%$ of the variance in the number of hate crime rates. The measures of demographic diversity had a low combined effect on the number of hate crime rates within the 21 counties of New Jersey. Based on the results of the regression analysis, it was determined that hate crime rates in New Jersey was not significantly affected by the demographic diversity within the 21 counties of New Jersey as measured by the percentage of nonWhites only in the different counties. As such, these results did not lead to the rejection of the null hypothesis for Research Question 1 that there is no significant relationship between demographic diversity and the number of hate crime rates in New Jersey.

To address Research Question 2, the analysis involved a regression analysis using the subvariables of social disorganization as the independent variable and hate crime rates as the dependent variable. The subvariables of social disorganization included (a) demographic diversity, measured using the percentage of non-Whites; (b) family disruption; (c) concentrated disadvantage, measured based on the unemployment rate; (d) residential mobility; (e) population size of density; and (f) and proximity to urban areas.

The results of the regression analysis indicate that the proposed model was statistically significant, with the subvariables of social disorganization accounting for $40 \%$ of the variance in the hate crime rates in New Jersey. This indicates a moderate effect between the variables. Among the six subvariables, increases in the residential mobility and population size of density resulted in increases in hate crimes, whereas decreases in concentrated disadvantage, which was measured based on unemployment rates, resulted in increases in the hate crime rates. Out of these three significantly associated variables, concentrated disadvantage had the greatest effect on the number of hate crime rates. 


\section{Residential Mobility}

For this research study, the variable residential mobility being significantly linked to hate crimes in New Jersey may be based on a neighborhood's inability to develop strong community ties (social disintegration; Bursik \& Grasmick, 1993) and not on an incoming group being perceived as a threat to an established group (Green, McFalls, \& Smith, 2001).

\section{Population Size of Density}

As indicated by the results of the data analysis, increases in population density significantly affect the increase in the incidence of hate crimes. Population size of density variable under social disorganization theory supports the social disorganization theory of the study and the demographic composition of the state because New Jersey is one of the most densely populated states in the United States with a population density of an average of 1,030 residents per square mile, 13 times that of the national average (50States.com, 2015). In regard to the proximity to urban areas variable, even though the results of this study did not signify a significant relationship between this variable and hate crimes, most counties in the state of New Jersey are considered urbanized, with about 90\% of the people residing in an urban area (50States.com, 2015). Because of this, the population size of density variable, which yielded a positive relationship to hate crime rates, is a more appropriate determining factor.

\section{Concentrated Disadvantage}

One unexpected finding of this study was the negative or inverse relationship between concentrated disadvantage and hate crime rates. Contrary to the results of the study, higher scores for concentrated disadvantage, as quantified by the unemployment rate, would lead to an increased level of hate crime rates. A review of existing literature outlines this expectation, which indicated that concentrated disadvantage creates social disruption, which in turn perpetuates an environment for crime and disorder (Bursik \& Grasmick, 1993). Anderson, Dyson, and Brooks (2006) maintained that in the 1990s, while crime statistics revealed an increase on overall crimes, the economic state of the country improved. It may be that a link between an increase in the job market that may lead to competition for higher paying positions or jobs.

\section{Statistical Limitations and Implications for the Study}

A statistical limitation to this study was the violation in the assumptions of linearity between the relationship of the independent variable and dependent variable for the regression results. These were violations of required assumption as the limitations to this study, and the results are unreliable as the model was not a fit. There were statistical issues with the results of the analysis. First was the autocorrelation or serial correlation violation, which indicated that there were some time effects present in the regression results because the Durbin-Watson statistics were in the danger territory for Research Question 1. The autocorrelation violation is a common occurrence in analysis involving time dependent data. Because of this violation, one should proceed with caution when interpreting the regression models. The autocorrelation violation was a weakness in this study, and future researchers should consider this violation to have a more significant statistical finding. Second, a longitudinal and panel data analysis was not employed, which future studies may consider.

\section{Conclusion}

The results of this study are relevant to members of various ethnic communities who may have been victims of hate crimes, legislators, and law enforcement agencies. The results help increased awareness and information on hate crimes that can be beneficial in educational counseling 
programs, public information programs, and victims counseling programs. Additionally, public policy initiatives may benefit states like New Jersey in addressing hate crimes. McVeigh, Bjarnason, and Welch (2003) contended that hate crime legislation is highly supported in ethnically heterogeneous communities because the residents of these communities are more likely to respond positively to problems stemming from an interethnic perspective. The formation of public policy initiatives includes the establishment institutional and educational programs, offender educational programs, and offender sentencing programs. Other initiatives include the establishment of new local ordinances, statutes, and leadership in response to hate crimes in the area of legislation.

Based on a review of the literature and the results of the study, proposed recommendations include a focus on further research on the negative experiences of victims who report hate crimes, determining motivation behind hate crimes, and the relationship between concentrated disadvantage and hate crimes. Another recommendation is that law enforcement agencies provide in-depth training to law enforcement personnel to identify hate crimes, improve procedures in reporting hate crimes to protect victims, and address the issue of the language barrier in reporting hate crimes. Additional recommendations include the establishment of community programs that promote strong bonds between various ethnic groups to mitigate the effects of social isolation that results in bias-motivated crimes.

The results of the study did not reveal a significant relationship based on the demographic composition of the state between hate demographic diversity, proximity to urban areas, and hate crimes. Based on the unique demographic composition of the state, the study's results did reveal a significant relationship between residential mobility, population density, and hate crimes. To address hate crimes in New Jersey, additional research on residential mobility and population density is recommended. The findings of this study are of relevance to the New Jersey community members, the legislative and law enforcement branches of government, and to the larger academic community. Increased information on the factors that contribute to hate crimes can result in positive solutions that decrease hate crime rates in New Jersey.

\section{References}

50States.com (2015). New Jersey facts and trivia. Retrieved from http://www.50states.com/facts//new jersey.htm

American Conference on Diversity. (2007). A report on the leadership conference on diversity issues impacting New Jersey: Findings of the statewide survey of New Jersey residents' attitudes about race and inter-group relations. Retrieved from http://www.americanconferenceondiversity.org/documents/ConfSummaryBochFINAL081808.pdf

Anderson, J. F., Dyson, L., \& Brooks Jr., W. (2005-2006). Preventing hate crime and profiling hate crime offenders. Western Journal of Black Studies, 4, 121-137.

Berger, M. E. (2009). NJ hate crime. Hate doesn't tell whole story. Retrieved from http://www.aolnews.com/2009/12/15/n-j-hate-crime-doesnt-tell-full-story/

Bursik, R., \& Grasmick, H. G. (1993). Neighbourhoods and crime: The dimensions of effective community control. Lexington, MA: Lexington Books.

Dance, R. A., \& Sandefur, J. T. (2004). How far away is that? Ratios, proportions, maps, and medicine (National Science Foundation Grant No. 0087068). Retrieved from http://www.uvi.edu/files/documents/College_of_Science_and_Mathematics/math_skills/11.pdf 
Gainey, R. R., Sun, I. Y., \& Triplett, R. (2004). Neighborhood characteristics and crime: A test of Sampson and Groves' model of social disorganization. Western Criminological Review, 5, 116. Retrieved from http://westerncriminology.org/documents/WCR/v05n1/article_pdfs/Sun.pdf

Grattet, R. (2009). The urban ecology of bias crime: A study of disorganized and defended neighborhoods. Social Problems, 56, 132-150. doi:10.1525/sp.2009.56.1.132

Green, D. P., McFalls, L. H., \& Smith, J. K. (2001). Hate crime: An emergent research agenda. Annual Review of Sociology, 27, 479. doi:10.1146/annurev.soc.27.1.479

Katz, D. (2012). Ten states with the most hate crimes per capita. Retrieved from http://blogs.findlaw.com/blotter/2012/12/10-states-with-the-most-hate-crimes-per-capita.html

Kornhauser, R. (1978). Social sources of delinquency. Chicago, IL: University of Chicago Press.

Kubrin, C. E. (2000). Racial heterogeneity and crime: Measuring static and dynamic effects. Research in Community Sociology, 10, 189-218. Retrieved from https://www.researchgate.net/publication/255699204_Racial_Heterogeneity_and_Crime_Mea suring_Static_and_Dynamic_Effects

McVeigh, R., Bjarnason, T., \& Welch, M. R. (2003). Hate crime reporting as a successful social movement outcome. American Sociological Review, 68, 843-867. doi:10.2307/1519748

New Jersey population density county rank. (2014). Retrieved from http://www.usa.com/rank/newjersey-state--population-density--county-rank.htm

New Jersey State Police, Uniform Crime Reporting Unit. (2011). Bias incidents in New Jersey for the year ending December 31, 2011 (twenty-fourth annual bias incident offense report). Retrieved from http://www.njsp.org/info/ucr2011/pdf/2011a_bias_incident_rpt.pdf

O’Dea, C. (2018). New Jersey's troubling trend, increase in bias and hate crimes. NJSpotlight. Retrieved from http://www.njspotlight.com/stories/18/04/01/new-jersey-s-troubling-trendincrease-in-bias-and-hate-crimes/

Osgood, D. W. \& Chambers, J. M. (2003, May). Community correlates of rural youth violence. OJJDP Juvenile Justice Bulletin, 193591. Retrieved from https://www.ncjrs.gov/pdffiles1/ojjdp/193591.pdf

Sampson, R. J., \& Bean, L. (2005). Cultural mechanisms and killing fields: A revised theory of community level racial inequality. Retrieved from http://ebooks.unair.ac.id/data/artikel/serbaserbi/culturalm3chanism.pdf

Sampson, R. J., \& Groves, W. B. (1989). Community structure and crime: Testing social disorganization theory. American Journal of Sociology, 94, 774-802. doi:10.1086/229068

Sampson, R. J., \& Wilson W. J. (1995). Toward a theory of race, crime, and urban inequality. In J. Hagan \& R. D. Peterson (Eds.), Crime and inequality (pp. 37-56). Stanford, CA: Stanford University Press.

Shaw, C. R., \& McKay, H. D. (1942). Juvenile delinquency and urban areas. Chicago, IL: University of Chicago Press.

Some NJ Facts. (2007). Jersey City online. Retrieved on August 27, 2013 from http://www.jerseycityonline.com/jerseycity/nj_facts_htm

Stacey, M. (2012). Bias crime and minority threat (Doctoral dissertation). Retrieved from http://irl.umsl.edu/dissertation/348 
StateMaster.com. (2011). Crime statistics: Hate crimes: Race related (most recent by state). Retrieved from http://www.statemaster.com/graph/cri_hat_cri_rac_rel-crime-hate-crimes-race related

U.S. Census Bureau. (1996). New Jersey metropolitan areas, counties, and central cities. United States Department of Commerce, Economics, and Statistics Administration. Retrieved from http://www.census.gov/prod/ec97/maps/ec97_ma_nj.pdf

U.S. states with the highest rate of reported hate crimes. (2013). Retrieved from http://www.aneki.com/america_hate_crimes_reported_state.html

[Appendix follows] 


\section{Appendix}

\section{Data References}

ACS Demographic and Housing Estimates. (2009). American community survey 1-year estimates. United States Census Bureau. Retrieved from http://factfinder2.census.gov/faces/tableservices/jsf/pages/ productview.xhtml?pid=ACS_09_1YR_CP5\&prodType=table

ACS Demographic and Housing Estimates. (2010). American community survey 1-year estimates. United States Census Bureau. Retrieved from http://factfinder2.census.gov/faces/tableservices/jsf/pages/productview.xhtml?pid=ACS_10_1Y R_DP05\&prodType=table

ACS Demographic and Housing Estimates. (2011). American community survey 1-year estimates. United States Census Bureau. Retrieved from http://factfinder2.census.gov/faces/tableservices/jsf/pages/productview.xhtml?pid=ACS_11_1Y R_DP05\&prodType $=$ Table

Geographic Mobility by Selected Characteristics in the United States. (2007). American community survey 1-year estimates. United States Census Bureau. Retrieved from http://factfinder2.census.gov/faces/tableservices/jsf/pages/productview.xhtml?pid=ACS_07_1Y R_S0701\&prodType=table

Geographic mobility by selected characteristics in the United States. (2008). American community survey 1-year estimates. United States Census Bureau. Retrieved from http://factfinder2.census.gov/faces/tableservices/jsf/pages/productview.xhtml?pid=ACS_08_1Y R_S0701\&prodType=table

Geographic mobility by selected characteristics in the United States. (2009). American community survey 1-year estimates. United States Census Bureau. Retrieved from http://factfinder2.census.gov/faces/tableservices/jsf/pages/productview.xhtml?pid=ACS_09_1Y R_S0701\&prodType=table

Geographic mobility by selected characteristics in the United States. (2010). American community survey 1-year estimates. United States Census Bureau. Retrieved from http://factfinder2.census.gov/faces/tableservices/jsf/pages/productview.xhtml?pid=ACS_10_1Y R_S0701\&prodType=table

Geographic mobility by selected characteristics in the United States. (2011). American community survey 1-year estimates. United States Census Bureau. Retrieved from http://factfinder2.census.gov/faces/tableservices/jsf/pages/productview.xhtml?pid=ACS_11_1Y R_S0701\&prodType=table

Hate crime statistics. (2007). Table 13. Hate crime incidents per bias motivation and quarter by state and agency. Federal Bureau of Investigation. Retrieved from https://www2.fbi.gov/ucr/hc2007/table_13nj.htm

Hate crime statistics. (2008). Table 13. Hate crime incidents per bias motivation and quarter by state and agency. Federal Bureau of Investigation. Retrieved from https://www2.fbi.gov/ucr/hc2008/table_13nj.htm 
Hate crime statistics. (2009). Table 13. Hate crime incidents per bias motivation and quarter by state and agency. Federal Bureau of Investigation. Retrieved from http://www2.fbi.gov/ucr/hc2009/data/table_13nj.html

Hate crime statistics. (2010). Table 13. Hate crime incidents per bias motivation and quarter by state and agency. Federal Bureau of Investigation. Retrieved from http://www.fbi.gov/aboutus/cjis/ucr/hate-crime/2010/tables/table-13/New-Jersey

Hate crime statistics. (2011). Table 13. Hate crime incidents per bias motivation and quarter by state and agency. Federal Bureau of Investigation. Retrieved from http://www.fbi.gov/aboutus/cjis/ucr/hate-crime/2011.tables/table-13-1/table_13_new-jersey_hate_crime_incidents_per_bias_motivation_and_quarter_by_state_and_agency_2011.xls

Local area unemployment statistics. (2007-2010). United States Bureau of Labor Statistics. Retrieved from http://data.bls.gov/pdq/SurveyOutputServlet

Local area unemployment statistics. (2011). United States Bureau of Labor Statistics. Retrieved from http://data.bls.gov/pdq/SurveyPutputServlet

Marital status. (2007). American community survey 1-year estimates. United States Census Bureau. Retrieved from http://factfinder2.census.gov/faces/tableservices/jsf/pages/productview.xhtml?pid=ACS_07_1Y R_S1201\&prodType=table

Marital status. (2008). American community survey 1-year estimates. United States Census Bureau. Retrieved from http://factfinder2.census.gov/faces/tableservices/jsf/pages/productview.xhtml?pid=ACS_08_1Y R_S1201\&prodType=table

Marital status. (2009). American community survey 1-year estimates. United States Census Bureau. Retrieved from http://factfinder2.census.gov/faces/tableservices/jsf/pages/productview.xhtml?pid=ACS_09_1Y R_S1201\&prodType=table

Marital status. (2010). American community survey 1-year estimates. United States Census Bureau. Retrieved from http://factfinder2.census.gov/faces/tableservices/jsf/pages/productview.xhtml?pid=ACS_10_1Y R_S1201\&prodType=table

Marital status. (2011). American community survey 1-year estimates. United States Census Bureau. Retrieved from http://factfinder2.census.gov/faces/tableservices/jsf/pages/productview.xhtml?pid=ACS_11_1Y R_S1201\&prodType=table

U.S. Census Bureau. (2007). American community survey 1-year estimates. Retrieved from http://factfinder2.census.gov/faces/tableservices/jsf/pages/productview.xhtml?pid=ACS_07_1Y R_DP5\&prodType=table

U.S. Census Bureau. (2008). American community survey 1-year estimates. Retrieved from http://factfinder2.census.gov/faces/tableservices.jsf/pages/productview.xhtml?pid=ACS_08_1Y R_CP5\&prodType=table 
The Journal of Social, Behavioral, and Health Sciences is an open-access, peer-reviewed, online interdisciplinary journal focusing on research findings that address contemporary national and international issues. Its objectives are to (a) encourage dialogue between scholars and practitioners in the social, behavioral, and health sciences that fosters the integration of research with practice; (b) promote innovative models of interdisciplinary collaboration among the social, behavioral, and health sciences that address complex social problems; and (c) inform the relationship between practice and research in the social, behavioral, and health sciences.

Walden University Publishing: http://www.publishing.waldenu.edu 